\title{
Numerical Simulation of Fatigue Crack Growth in Titanium Alloy Orthopaedic Plates
}

\author{
Filip VUČETIĆ*, Katarina ČOLIĆ, Aleksandar GRBOVIĆ, Ana PETROVIĆ, Aleksandar SEDMAK, Dražan KOZAK, Simon SEDMAK
}

\begin{abstract}
Biomaterials intended for orthopaedic plates manufacturing have much higher mechanical properties relative to the bone itself and still there are many cases where those plates fracture in service, with fatigue as the main failure mode. This causes problem with the healing process and requires that the patient undergoes another surgery. Experience and knowledge of the orthopaedic surgeon is one of the most important factors contributing to the frequency of fatigue failures. If incorrectly implanted, plates will be subjected to overloading from the start, which is convenient for crack initiation. One of the most commonly used biocompatible materials for internal bone fixation is $\alpha+\beta$ titanium alloy Ti-6Al-4V. Focus of this study was to simulate the behaviour of titanium alloy orthopaedic plates in the presence of cracks under four-point bending. The extended finite element method (XFEM) in ANSYS was employed for this purpose. Loads correspond to the ones occurring in human tibia during gait cycle for different body weights. Experimental investigation of tensile and fracture mechanics parameters of Ti-6Al-4V alloy was conducted on tensile testing machine and fractomate. Numerical simulation established the optimal geometry from remaining life point of view, indicating large differences between different geometries. Results also have shown that the remaining life of orthopaedic plates is strongly dependant on patient's body weight (load) and that the relative differences in remaining life between compared plate geometries stay the same under different loads. Influence of corrosive environment of the human body was not taken into consideration.
\end{abstract}

Keywords: ASTM F382; crack growth; orthopaedic plates, Ti-6AI-4V; XFEM

\section{INTRODUCTION}

Owing to its good mechanical properties, outstanding corrosion stability and biocompatibility, $\alpha+\beta$ titanium alloy Ti-6Al-4V has been most frequently used for orthopaedic plates manufacturing [1-4]. Fatigue fracturing has shown to be the most common failure mode of in-service orthopaedic plates. Fatigue, as a process of defect accumulation, i.e. crack initiation and propagation due to bending cycles, is likely to occur even under low cycling load. Also, orthopaedic surgeon's experience is crucial for avoiding overloads of the implant due to incorrect implantation [5-7], which can easily cause crack initiation in combination with stress concentration locations [8].

American Society for Testing and Materials (ASTM) has issued a standard [9] for testing metallic bone plate stating that the time frame, number of loading cycles and loading conditions are uncontrollable and unpredictable. Also, there is no acceptable limit for the bending moment or number of cycles which the bone plate should withstand. Testing prescribed in this standard is used for comparison between materials, different designs and materials.

Having the seriousness of plate in-service failure, it is necessary to approach the subject of structural integrity and life of internal fixation devices from all possible aspects. Numerical simulations are widely used for assessing the different behaviours of various implants, such as: artificial hips, dental implants, etc. [10-14]. This study is a step towards explaining the behaviour of different orthopaedic plate designs, under uniaxial bending, with cracks initiated at the stress concentration areas. Probably the most efficient experimental method would be the optical strain measurement systems $[8,15,16]$, especially since commercial crack length foils are hardly possible to be used on orthopaedic plates. Here, numerical simulations in ANSYS were used for XFEM simulations based on experimentally determined material parameters. Basic aims were to evaluate remaining life of orthopaedic plates depending on different geometries, so that the optimal one can be seleceted, and to assess the effect of human weight, i.e. loading.

\section{EXPERIMENTAL INVESTIGATION}

Tenile and fatigue crack growth testing of Ti-6Al-4V alloy was performed at the Laboratory for Materials testing, Military Technical Institute in Belgrade, providng results for structural integrity and life assessment of reconstructive plates.

\subsection{Tensile Testing}

Tensile testing was conducted according to EN ISO 6891-1 [17], using a servo hydraulic tensile tester with the $\pm 100 \mathrm{kN}$ force range, in deformation (elongation) control, under loading rate of $5 \mathrm{~mm} / \mathrm{min}$. Test results are presented in Tab. 1 .

Table 1 Tensile testing results

\begin{tabular}{|c|c|c|c|}
\hline Sample no. & $\begin{array}{c}\text { Yield strength, } \\
R_{p 0,2} / \mathrm{MPa}\end{array}$ & $\begin{array}{c}\text { Ultimate strength } \\
R_{m} / \mathrm{MPa}\end{array}$ & $\begin{array}{c}\text { Elongation } \\
A / \%\end{array}$ \\
\hline 1 & 1035 & 1089 & 7,7 \\
\hline 2 & 1015 & 1062 & 6,0 \\
\hline 3 & 1022 & 1071 & 6,6 \\
\hline
\end{tabular}

\subsection{Fracture Mechanics Parameters}

Room temperature testing of crack growth rate $(\mathrm{d} a / \mathrm{d} N)$ and threshold value of stress intensity factor $\Delta K_{t h}$ is performed on Charpy test samples, via three point bending method on resonant high frequency pulsator. Testing was done according to ASTM E647 [18], it was load controlled, under load ratio of $R=0.1$, in $215-235 \mathrm{~Hz}$ frequency range. Average load and amplitudes were measured with $\pm 3 \mathrm{Ncm}$ accuracy.

Table 2 Fatigue crack growth parameters

\begin{tabular}{|c|c|c|c|}
\hline $\begin{array}{c}\text { Sample } \\
\text { no. }\end{array}$ & $\begin{array}{c}\text { Stress intensity factor } \\
\Delta K_{\text {th }} / \mathrm{MPa} \mathrm{m}^{1 / 2}\end{array}$ & $\begin{array}{c}\text { Coefficient } \\
C\end{array}$ & $\begin{array}{c}\text { Exponent } \\
m\end{array}$ \\
\hline 1 & 4,5 & $1,54 \cdot 10^{-12}$ & 2,15 \\
\hline 2 & 4,8 & $3,70 \cdot 10^{-13}$ & 2,31 \\
\hline 3 & 4,7 & $1,05 \cdot 10^{-13}$ & 2,32 \\
\hline
\end{tabular}

Measurement system is based on indirect potential drop method and continuously indicates the measurement 
values. It generates an accurate result of the crack length and can also be used to control the propagation of the crack. Test procedure and calculation is described in detail elsewhere $[19,20]$, whereas test results are given in Tab. 2.

\section{NUMERICAL SIMULATIONS}

Extended finite element method (XFEM) in ANSYS software was employed for the purpose of simulating the fatigue crack growth in orthopaedic plates. Numerical simulations were used instead of experimental approach due to cost and time effectiveness. Analysis includes 5 different plate geometries, marked with: A, B, C, D and E (Fig. 1, Fig. 2, Fig. 3, Fig. 4 and Fig. 5). Cross sections B$\mathrm{B}$ on each plate's drawing show the location and size $(\mathrm{R}=$ $0.5 \mathrm{~mm}$ ) of initial cracks. Example of initial crack mesh is shown in Fig. 11.

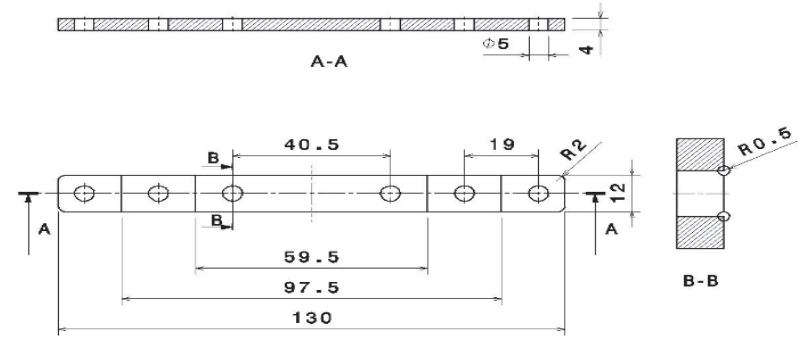

Figure 1 Plate A geometry

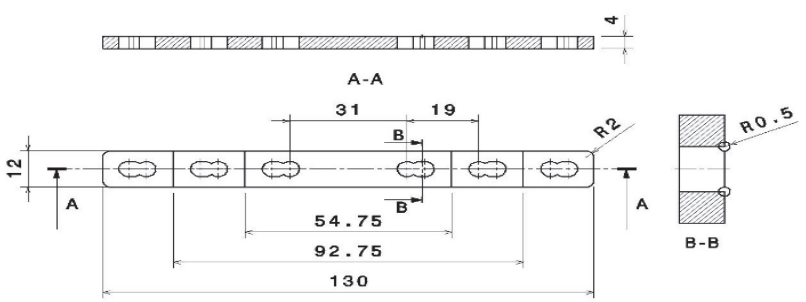

Figure 2 Plate B geometry

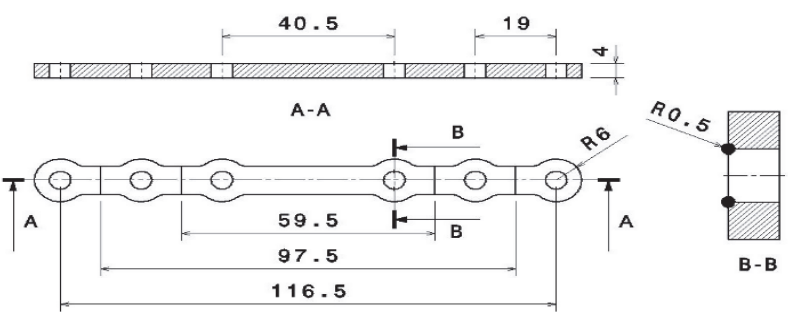

Figure 3 Plate $\mathrm{C}$ geometry

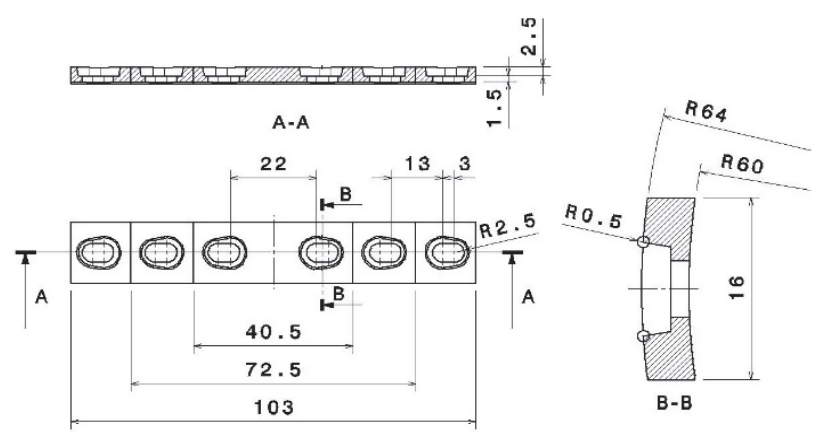

Figure 4 Plate D geometry

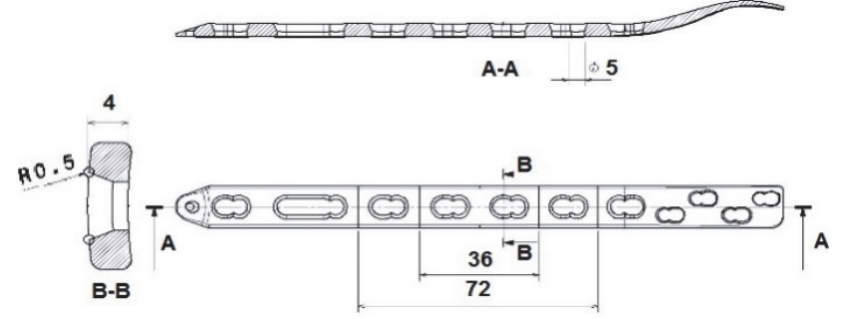

Figure 5 Plate E geometry

Tetrahedral finite elements (10 nodes) mesh was generated for every type of plate (Fig. 6, Fig. 7, Fig. 8, Fig. 9 and Fig. 10). Number of finite elements, their average size and number of nodes per plate is presented in Tab. 3 .

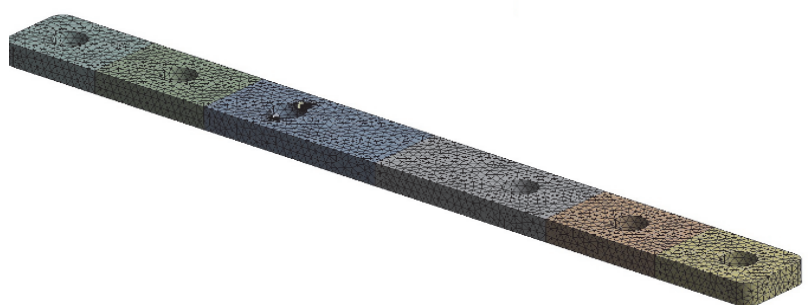

Figure 6 Plate A mesh with initial cracks

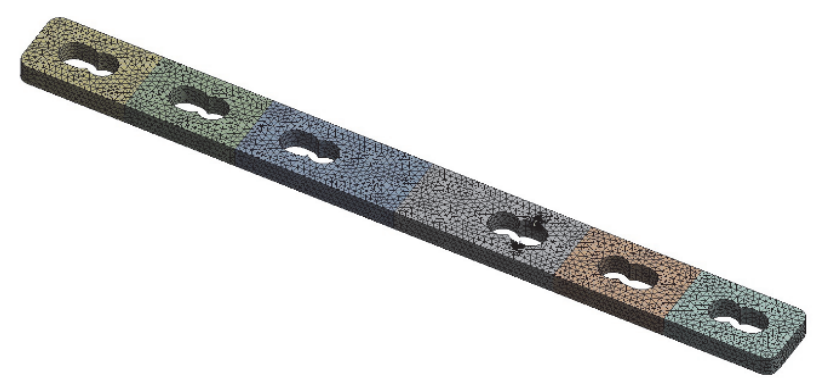

Figure 7 Plate B mesh with initial cracks

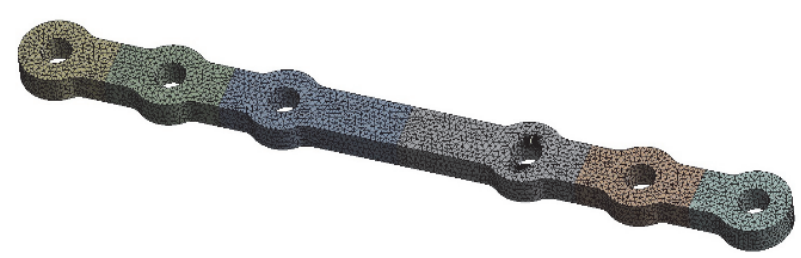

Figure 8 Plate $\mathrm{C}$ mesh with initial cracks

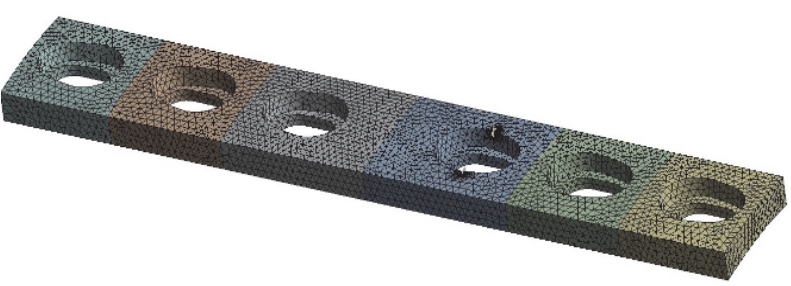

Figure 9 Plate D mesh with initial cracks

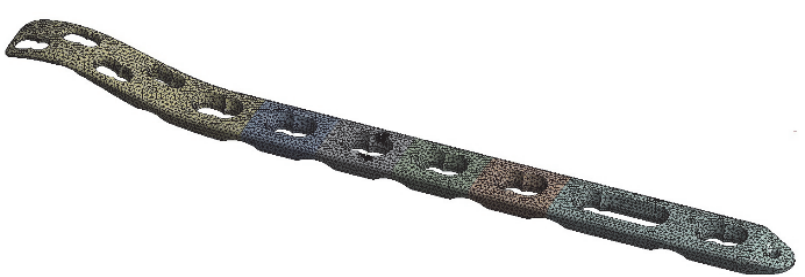

Figure 10 Plate E mesh with initial cracks 


\begin{tabular}{|c|c|c|c|}
\hline Plate type & $\begin{array}{c}\text { Number of finite } \\
\text { elements }\end{array}$ & $\begin{array}{c}\text { Average element } \\
\text { size } / \mathrm{mm}\end{array}$ & $\begin{array}{c}\text { Number of } \\
\text { nodes }\end{array}$ \\
\hline A & 40614 & 1,18580 & 63020 \\
\hline B & 69386 & 0,98465 & 109765 \\
\hline $\mathrm{C}$ & 67457 & 0,84443 & 104213 \\
\hline D & 71599 & 0,90758 & 108990 \\
\hline $\mathrm{E}$ & 57196 & 0,57034 & 88534 \\
\hline
\end{tabular}

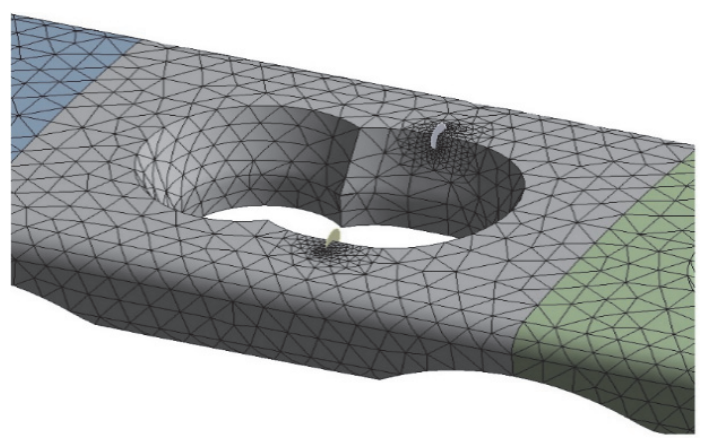

Figure 11 Mesh detail around the initial crack

Conditions described in ASTM F382 [9] were taken as a basis for simulation of four-point bend testing. Maximal bending moments in the human tibia (upper tibia region) were approximately calculated, according to Wehner T. et al. [21], for 60,90 and $120 \mathrm{~kg}$ body weights (BW). In this setup, orthopaedic plates can be observed as simple beams for which the loading forces and support reactions can be determined thus the calculated bending moments are between loading points (Tab. 4). Locations of supports (points $\mathrm{A}$ and $\mathrm{B}$ ), loading points (points $\mathrm{C}$ and $\mathrm{D}$ ) are presented in Fig. 12 for plate $\mathrm{D}$, as an example. $R$-ratio was set to 0.1 . Total of 60 steps were set in ANSYS.

Experimentally determined mechanical properties and crack growth parameters were used alongside predefined material parameters existing in ANSYS.

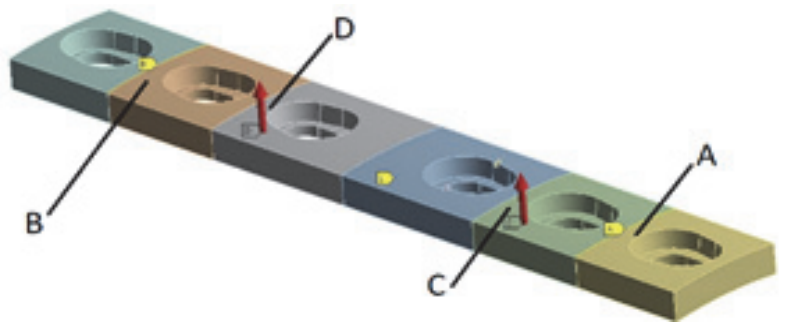

Figure 12 Supports and loading points locations, plate D

Table 4 Loading forces

\begin{tabular}{|c|c|c|c|}
\hline \multirow{2}{*}{ Plate type } & $\begin{array}{c}60 \mathrm{~kg} \mathrm{BW} / \\
\mathrm{kN}\end{array}$ & $\begin{array}{c}90 \mathrm{~kg} \mathrm{BW} / \\
\mathrm{kN}\end{array}$ & $120 \mathrm{~kg} \mathrm{BW} / \mathrm{kN}$ \\
\hline $\mathrm{A}$ & 2,2 & 3,3 & 4,4 \\
\hline $\mathrm{B}$ & 2,2 & 3,3 & 4,4 \\
\hline $\mathrm{C}$ & 2,2 & 3,3 & 4,4 \\
\hline $\mathrm{D}$ & 2,6 & 3,9 & 5,2 \\
\hline E & 2,3 & 3,45 & 4,6 \\
\hline
\end{tabular}

\section{RESULTS}

The XFEM analysis results are presented in Tab. 5 to Tab. 7 and in Fig. 13 to Fig. 15. As body weights increase, the life of orthopaedic plates decreases. After crack initiation, the remaining life of all plates, under the $120 \mathrm{~kg} \mathrm{BW}$ and $90 \mathrm{~kg}$ BW of load, is $\approx 80 \%$ and $\approx 60 \%$ shorter when compared to the $60 \mathrm{~kg}$ BW case, respectively. Differences between compared plate geometries, in regard to remaining life, stay the same with changes in load, as shown in Fig. 13 to Fig. 15. Plate $\mathrm{C}$ has the shortest remaining life in all three cases. Its design, made for providing less contact surface with bone, makes the plate less durable after crack initiation when compared to all other plates. Plates A and B have nearly identical remaining life in all three cases, while the remaining life of the plate E was somewhat shorter. The best geometry under given test conditions was of plate $\mathrm{D}$. If we assume that the average number of walking steps for a person making a recovery after getting an internal fixation device is cca. 1000 [9], it can be easily calculated how many days of walking could bring the orthopaedic plate made of Ti-6Al-4V to fracture after the crack initiation. Patients should keep their physical activity on minimal level and not apply full walking load for a few months at least after the surgery.

Table 5 XFEM analysis results - $60 \mathrm{~kg} \mathrm{BW}$

\begin{tabular}{|c|c|c|c|}
\hline $\begin{array}{l}\text { Plate } \\
\text { type }\end{array}$ & Number of cycles & $\begin{array}{c}\text { Stress intensity } \\
\text { factor / } \mathrm{MPa} \mathrm{mm} \mathrm{mm}^{1 / 2}\end{array}$ & $\begin{array}{c}\text { Maximal crack } \\
\text { length / mm }\end{array}$ \\
\hline $\mathrm{A}$ & 65520 & 2256 & 6,4696 \\
\hline $\mathrm{B}$ & 67831 & 2102 & 6,2486 \\
\hline $\mathrm{C}$ & 43399 & 2791 & 6,2452 \\
\hline $\mathrm{D}$ & 100670 & 1748 & 6,3982 \\
\hline $\mathrm{E}$ & 58897 & 2150 & 6,1719 \\
\hline
\end{tabular}

Results of XFEM show that the maximal obtained crack length is more than $2 \mathrm{~mm}$ longer than the plate thicknesses. This is explained by showing the crack propagation path of plate A, given in Fig. 16. In the beginning, crack propagates equally through the plate thickness and along the surface, up to the point where the crack predominantly starts propagating along the surface. When the crack gets along the surface to the full width of the plate it then continues with fast propagation through plate thickness, thus making the longer path then just $4 \mathrm{~mm}$ of the plate's thickness. Same crack path (striation marks) was noticed by experimental 4 - point bend testing of orthopaedic plate made of 316L stainless steel and similar geometry to the one of plate E, made by Mohajerzadeh S. et al. [22] which is shown in Fig. 17.

\begin{tabular}{|c|c|c|c|}
\multicolumn{5}{|c}{ Table 6 XFEM analysis results - 90 kg BW } \\
\hline $\begin{array}{c}\text { Plate } \\
\text { type }\end{array}$ & Number of cycles & $\begin{array}{c}\text { Stress intensity } \\
\text { factor / MPamm }\end{array}$ & $\begin{array}{c}\text { Crack length / } \\
\mathrm{mm}\end{array}$ \\
\hline A & 25472 & 3396 & 6,5074 \\
\hline B & 26584 & 3152 & 6,2581 \\
\hline C & 16902 & 4205 & 6,294 \\
\hline D & 39016 & 2672 & 6,7589 \\
\hline E & 23066 & 3225 & 6,1592 \\
\hline
\end{tabular}

Table 7 XFEM analysis results $-120 \mathrm{~kg} \mathrm{BW}$

\begin{tabular}{|c|c|c|c|}
\hline $\begin{array}{c}\text { Plate } \\
\text { type }\end{array}$ & Number of cycles & $\begin{array}{c}\text { Stress intensity } \\
\text { factor / MPa mm }\end{array}$ & $\begin{array}{c}\text { Maximal crack } \\
\text { length / mm }\end{array}$ \\
\hline A & 13097 & 4528 & 6,1167 \\
\hline B & 13673 & 4203 & 6,347 \\
\hline C & 8674 & 5607 & 6,2529 \\
\hline D & 20068 & 3563 & 6,5785 \\
\hline E & 11967 & 4268 & 6,151 \\
\hline
\end{tabular}




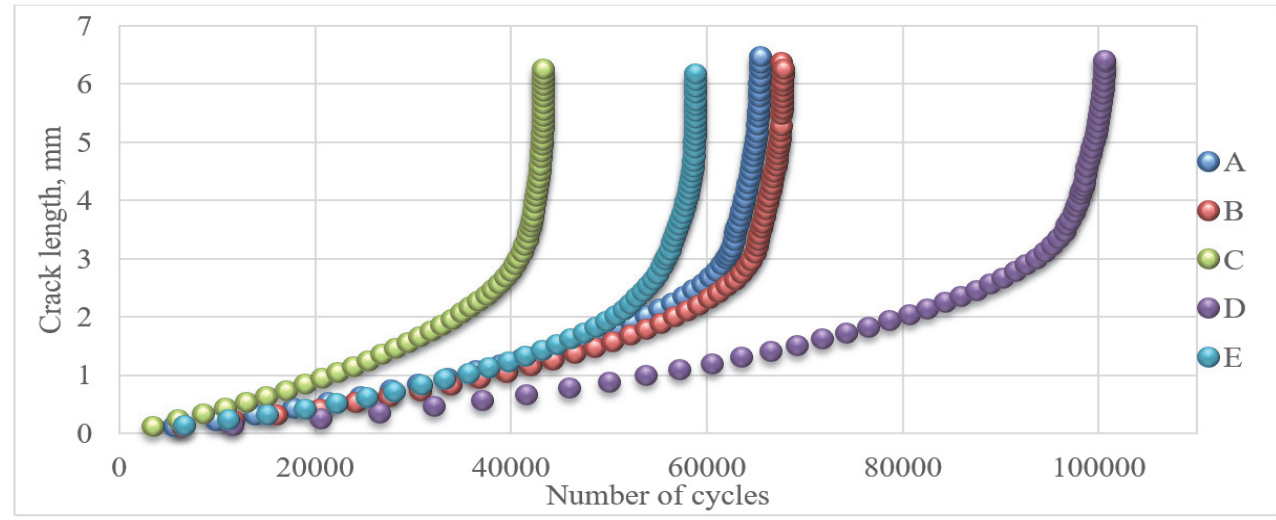

Figure 13 Crack length vs. Number of cycles $-60 \mathrm{~kg}$ BW

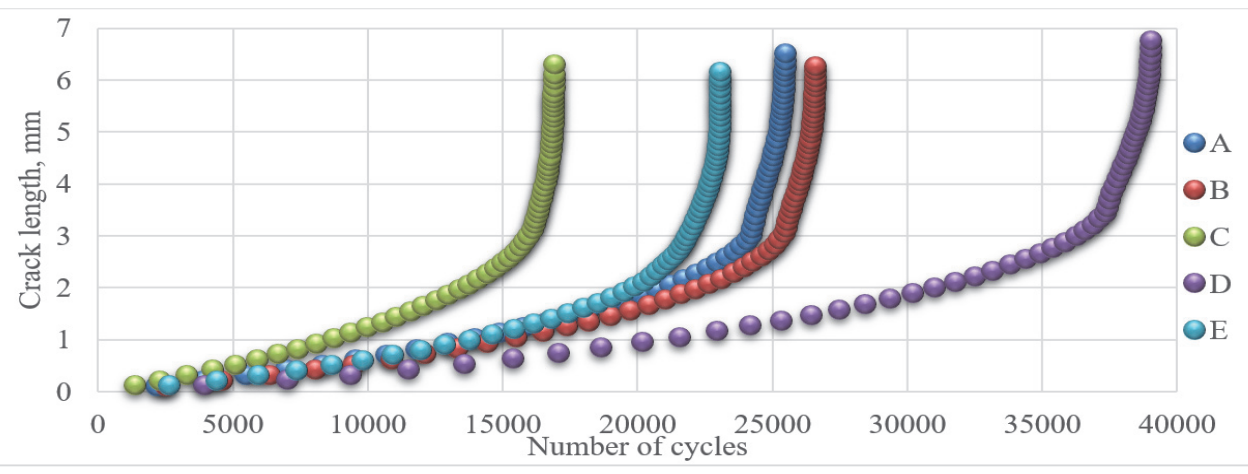

Figure 14 Crack length vs. Number of cycles - $90 \mathrm{~kg}$ BW

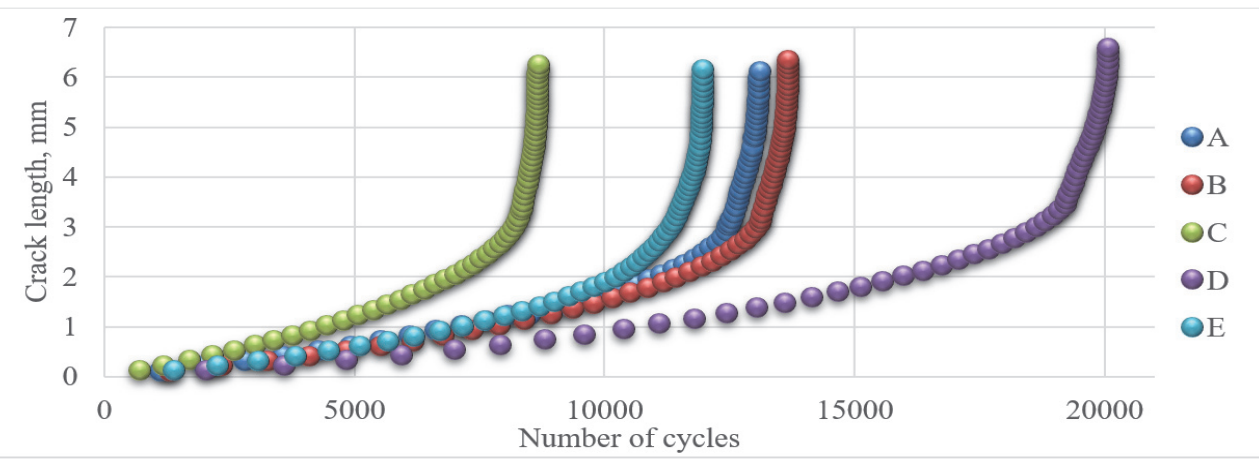

Figure 15 Crack length vs. Number of cycles $-120 \mathrm{~kg} \mathrm{BW}$

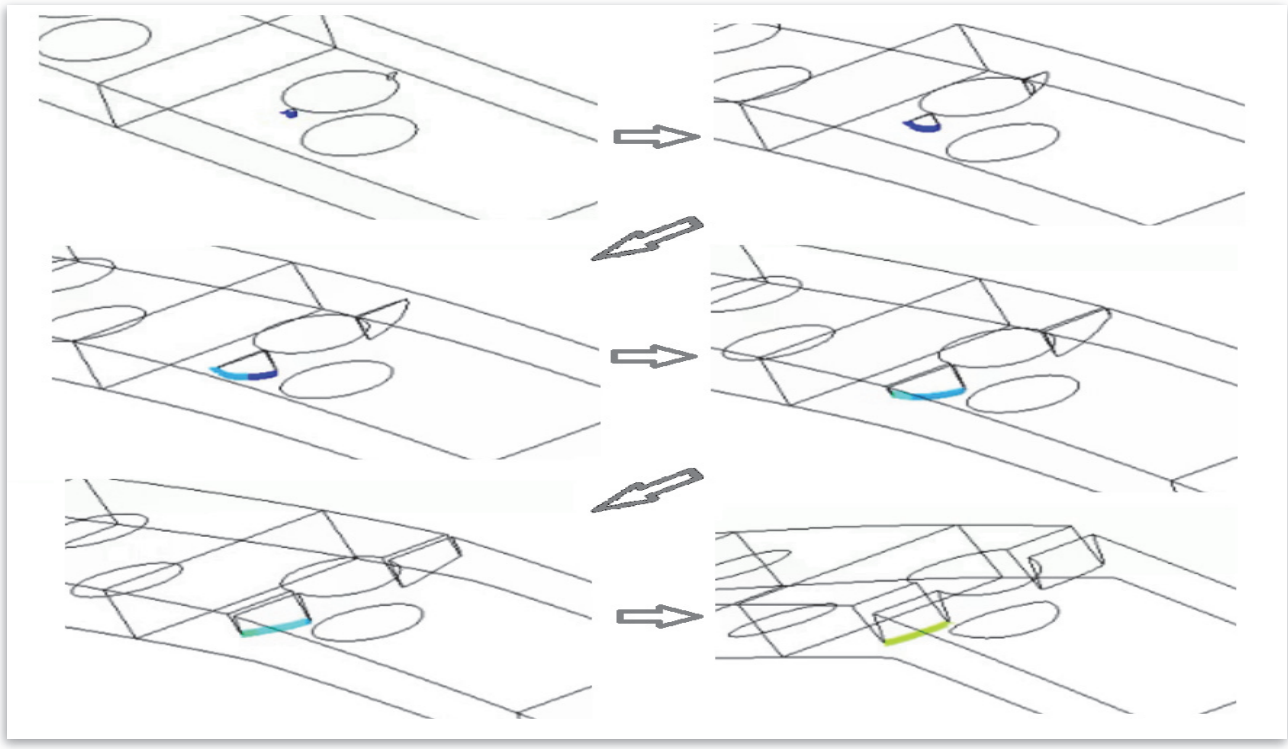

Figure 16 Crack propagation through material-plate A example 


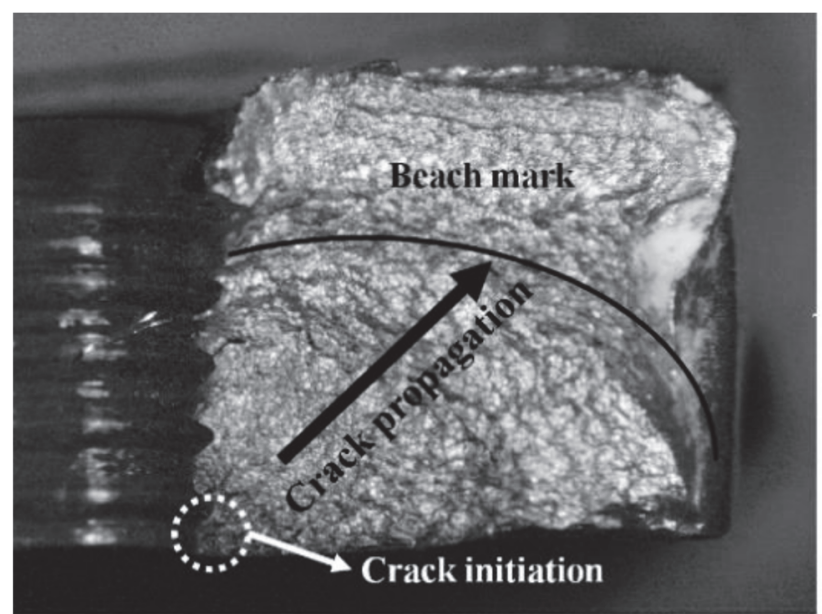

Figure 17 Crack propagation through $316 \mathrm{~L}$ steel plate under 4 - point bending [22]

\section{CONCLUSIONS}

Remaining life assessment of Ti-6Al-4V orthopaedic plates after crack initiation was conducted by means of extended finite element method (XFEM) in ANSYS software. Four point bending of five different plate geometries was analysed under three load magnitudes occurring in the tibia. Following conclusions can be drawn: - After crack initiation, the remaining life of all plates, under the $120 \mathrm{~kg} \mathrm{BW}$ and $90 \mathrm{~kg} \mathrm{BW}$ of load, is $\approx 80 \%$ and $\approx 60 \%$ shorter when compared to the $60 \mathrm{~kg}$ BW case, respectively.

Differences in remaining life between compared plate geometries stay the same under different loads.

Plate designed for providing less contact with bone surface has the shortest remaining life.

- Crack propagation path is more than $2 \mathrm{~mm}$ longer than the plate's thickness in all cases, since the crack stops propagating through thickness at one point and continues along plate surface only. When the surface propagation finishes, crack starts going through the thickness again and faster. This information can be taken in consideration when designing the plates in order to prolong the remaining life after crack initiation.

Patient should keep his physical activity on minimal level and not apply full walking load for a few months after the surgery at least.

\section{Acknowledgement}

This work is supported by the Ministry of Education, Science and Technological Development of the Republic of Serbia under the project TR 35040.

\section{REFERENCES}

[1] Oldani, C. \& Dominguez, A. (2012). Titanium as a Biomaterial for implants, in Fokter S.: Recent Advances in Arthroplasty, 149-162. https://doi.org/10.5772/27413

[2] Hosseini, S., Hudak, R., et al. (2012). Fatigue of Ti-6Al-4V. Biomedical Engineering-Technical Applications in Medicine, 75-92. https://doi.org/10.5772/45753

[3] Pohler, O. E. M. (2002). Failures of Metallic Orthopedic Implants, ASM Handbook, 11, Failure analysis and prevention, ASM International. https://doi.org/10.31399/asm.hb.v11.a0001819
[4] ASTM F1472-14, Standard Specification for Wrought Titanium-6Aluminum-4Vanadium Alloy for Surgical Implant Applications (UNS R56400).ASTM International https://doi.org/10.1520/F1472-14

[5] Brunner, H. \& Simpson, J. P. (1980). Fatigue fracture of bone plates. Injury: The British Journal of Accident Surgery, 11, 203-207. https://doi.org/10.1016/S0020-1383(80)80044-1

[6] Kanchanomai, C., Phiphobmongkol, V., \& Muanjan, P. (2008). Fatigue failure of an orthopaedic implant-A locking compression plate. Engineering Failure Analysis, 15, 521530. https://doi.org/10.1016/..engfailanal.2007.04.001

[7] Azevedo, C. R. F., \& Hippert, Jr. E. (2002). Failure Analysis of surgical implants in Brazil. Engineering Failure Analysis, 9, 621-633. https://doi.org/10.1016/S1350-6307(02)00026-2

[8] Tatić, U., Čolić, K., Sedmak, A., Mišković, Ž., \& Petrović, A. (2018). Evaluation of the Locking Compression Plates StressStrain Fields. Technical Gazette, 25(1), 112-117. https://doi.org/10.17559/TV-20170420121538

[9] ASTM F382-17, Standard Specification and Test Method for Metallic Bone Plates. ASTM International. https://doi.org/10.1520/F0382-17

[10] Milovanovic, A., Sedmak, A., Čolić, K., Tatić, U., \& Đorđević, B. (2017). Numerical Analysis of Stress Distribution in Total Hip Replacement Implant. Structural Integrity and Life, 17(2), 139-144

[11] Sedmak, A., Čolić, K., Grbović, A., Balac, I., \& Burzić, M. (2019). Numerical Analysis of Fatigue Crack Growth of Hip Implant. Engineering Fracture Mechanics, 216, 106492. https://doi.org/10.1016/j.engfracmech.2019.106492

[12] Mijatović, T., Milovanović, A., Sedmak, A., Milović, Lj., \& Čolić, K. (2019). Integrity Assessment Of Reverse Engineered Ti-6Al-4V ELI Total Hip Replacement Implant. Structural Integrity and Life, 19(3), 237-242.

[13] Čolić, K., Grbović, A., Sedmak, A., \& Legweel K. (2019). Application of Numerical Methods in Design and Analysis of Orthopedic Implant Integrity. In: Mitrovic N., Milosevic M., Mladenovic G. (eds). Experimental and Numerical Investigations in Materials Science and Engineering. CNNTech 2018. Lecture Notes in Networks and Systems, vol 54. Springer, Cham., 96-111. https://doi.org/10.1007/978-3-319-99620-2_8

[14] Tatić, U., Miletić, V., Sedmak, S., Mitrović, N., Ezdenci, A., Gubeljak, L., \& Milošević, M. (2014). Influence Of The Cavity Shape In Restorative Dentistry On The Stress-Strain Distribution In Dentine And Enamel Caused By Polymerization. Structural Integrity and Life, 14(3), 199-204.

[15] Glaser, B., Predan, J., Kozak, D., \& Gubeljak, N. (2019). Comparison between Stereo Optical Strain Measurements and Finite Element Results in Stress Concentration Zones. Technical Gazette, 2(5), 1346-1352. https://doi.org/10.17559/TV-20190224220311

[16] Čolić, K., Burzić, M., Gubeljak, N., Petronić, S., \& Vučetić, F. (2017). Digital Image Correlation Method in Experimental Analysis of Fracture Mechanics Parameters. Scientific Technical Review, 67(2), 47-53. https://doi.org/10.5937/str1702047C

[17] EN ISO 6891-1, Metallic materials-Tensile testing-Part 1: Method of test at room temperature.

[18] ASTM E647-15, Standard Test Method for Measurement of Fatigue Crack Growth Rates.ASTM International. https://doi.org/10.1520/E0647-15E01

[19] Čamagić, I., Vasić, N., Vasić, Z., Burzić, Z., \& Sedmak, A. (2013). Compatibilityof Fracture Mechanics Parameters and Fatigue Crack Growth Parameters in Welded Joint Behaviour Evaluation. Technical Gazette, 20(2), 205-211.

[20] Novoselac, S., Kozak, D., Ergic, T., Damjanovic, D. (2017). Fatigue Damage Assessment of Bolted Joint Under Different Preload Forces and Variable Amplitude Eccentric Forces for High Reliability. Pluvinage, G., Milovic, Lj. (eds). Fracture at 
all scale. Lecture Notes in Mechanical Engineering, 239-268. https://doi.org/10.1007/978-3-319-32634-4_13

[21] Wehner, T., Claes, L., \& Simon, U. (2009). Internal loads in the human tibia during gait. Clinical Biomechanics, 24, 299302. https://doi.org/10.1016/j.clinbiomech.2008.12.007

[22] Mohajerzadeh, S., Farhangdoost, K., Zamani, P., \& Kolasangiani, K. (2018). Experimental Investigation on Fatigue Evaluation of Orthopaedic Locking Compression Plate. International Journal of Advanced Design and Manufacturing Technology, 11(4), 47-52.

\section{Contact information:}

Filip VUČETIĆ, M.Sc.ME, Research Assistant

(Corresponding author)

Innovation Center of Faculty of Mechanical Engineering, Belgrade,

Kraljice Marije 16, 11120 Belgrade, Republic of Serbia

E-mail: fvucetic@mas.bg.ac.rs

Katarina ČOLIĆ, PhD, Senior Research Associate

Innovation Center of Faculty of Mechanical Engineering, Belgrade,

Kraljice Marije 16, 11120 Belgrade, Republic of Serbia

E-mail: kbojic@mas.bg.ac.rs

Aleksandar GRBOVIĆ, PhD, Full Professor

University of Belgrade, Faculty of Mechanical Engineering,

Kraljice Marije 16, 11120 Belgrade, Republic of Serbia

E-mail: agrbovic@mas.bg.ac.rs

Ana PETROVIĆ, PhD, Assistant Professor

University of Belgrade, Faculty of Mechanical Engineering,

Kraljice Marije 16, 11120 Belgrade, Republic of Serbia

E-mail: aspetrovic@mas.bg.ac.rs

Aleksandar SEDMAK, PhD, Full Professor

University of Belgrade, Faculty of Mechanical Engineering,

Kraljice Marije 16, 11120 Belgrade, Republic of Serbia

E-mail: asedmak@mas.bg.ac.rs

Dražan KOZAK, PhD, Full Professor

Mechanical Engineering Faculty in Slavonski Brod,

University of Slavonski Brod,

Trg Ivane Brlic Mazuranic 2, HR-35000 Slavonski Brod, Croatia

E-mail: drazan.kozak@sfsb.hr

Simon SEDMAK, PhD, Research Associate

Innovation Center of Faculty of Mechanical Engineering, Belgrade,

Kraljice Marije 16, 11120 Belgrade, Republic of Serbia

E-mail: simon.sedmak@yahoo.com 